AperTO - Archivio Istituzionale Open Access dell'Università di Torino

\title{
Bradykinin in asthma: Modulation of airway inflammation and remodelling
}

\section{This is the author's manuscript}

Original Citation:

\section{Availability:}

This version is available http://hdl.handle.net/2318/1691884

since 2019-09-05T12:38:15Z

Published version:

DOI:10.1016/j.ejphar.2018.03.017

Terms of use:

Open Access

Anyone can freely access the full text of works made available as "Open Access". Works made available under a Creative Commons license can be used according to the terms and conditions of said license. Use of all other works requires consent of the right holder (author or publisher) if not exempted from copyright protection by the applicable law. 


\section{Bradykinin in asthma: modulation of airway inflammation and}

\section{remodelling}

Fabio L.M. Ricciardolo' ${ }^{1}$, Gert Folkerts ${ }^{2}$, Anna Folino ${ }^{1}$, Barbara Mognetti ${ }^{1}$

${ }^{1}$ Department of Clinical and Biological Sciences, University of Torino, Torino, Italy

${ }^{2}$ Department of Pharmacology, Utrecht Institute for Pharmaceutical Sciences, University of Utrecht, Utrecht, NL

Corresponding Author:

Prof. Fabio L.M. Ricciardolo, MD and PhD

Department of Clinical and Biological Sciences

University of Torino

A.O.U. San Luigi Gonzaga

Regione Gonzole 10

10043 - Orbassano (Torino), Italy 


\begin{abstract}
Bradykinin, a pro-inflammatory molecule, and its related peptides have been studied for their effects on acute reactions in upper and lower airways, where they can be synthesised and metabolized after exposure to different stimuli including allergens and viral infection. Bradykinin $\mathrm{B}_{1}$ and $\mathrm{B}_{2}$ receptors are constitutively expressed in the airways on several residential and/or immune cells. Their expression can also be induced by inflammatory mediators, usually associated with eosinophil and neutrophil recruitment, such as IL-4, IL-13, TNF- $\alpha$, IL-6 and IL-8, via intracellular MAPK and NF- $\kappa B$ signalling. In turn, the latters up-regulate both bradykinin receptors. Bradykinin activates epithelial/endothelial and immune cells, neurons and mesenchymal cells (such as fibroblasts, myofibroblasts and smooth muscle cells), which are implicated in the development of airway chronic inflammation, responsiveness and remodelling (a major feature of severe asthma). This review highlights the role of bradykinin and its receptors in respect to chronic inflammatory response involving eosinophils/neutrophils and to vascular/matrix-related airway remodelling in asthmatic airways. This scenario is especially important for understanding the mechanisms involved in the pathogenesis of eosinophilic and/or neutrophilic asthma and hence their therapeutic approach.
\end{abstract}

KEY WORDS: bradykinin, bradykinin receptors, asthma, severe asthma, airway inflammation, airway remodelling. 


\section{Introduction}

Bradykinin is a key regulator of vascular tone, acute inflammation, pain and cancer (Kaplan et al., 2002; Leeb-Lundberg et al., 2005; Kashuba et al., 2013). In asthma, bradykinin induces acute inflammatory responses in the airways, including plasma protein extravasation and smooth muscle contraction leading in turn to airway obstruction (Abraham et al., 2006). Acute anaphylactic response in allergic asthma is characterised by mast cells-derived mediators of inflammation and kinins formation with subsequent involvement of tachykinins (Geppetti et al., 1995). Furthermore, bradykinin is an indirect stimulus of bronchial hyperresponsiveness (Van Schoor et al., 2000) and a negative modulator of excessive bronchoconstriction, via the release of epithelium-derived bronchoprotective factors in asthma (Figini et al., 1996; Ricciardolo et al., 1996).

The bradykinin pathway is also involved in several processes related to asthma pathophysiology, such as the recruitment of eosinophils (Gurusamy et al., 2016) and neutrophils (Sodhi et al., 2017), the synthesis of "nitrosative stress" products (MacPherson et al., 2001; Fitzpatrick et al., 2009; Ricciardolo et al. 2006; Ricciardolo et al., 2012) and vascular/matrix-related remodelling (Ricciardolo et al., 2013). This review is focused on recent discoveries regarding the capability of bradykinin to amplify inflammatory responses and to influence cellular/molecular pathways involved in airway remodelling in asthma.

\section{Synthesis and physiological effects of bradykinin}

Bradykinin is produced by enzymatic cleavage of high and low molecular weight kininogens located, respectively in plasma and tissues. Specifically, plasma kallikrein cleaves high molecular weight kininogens while tissue kallikrein acts on low molecular weight kininogens. Both enzimes produce two low-molecular-weight vasoactive peptides: the nonapeptide bradykinin (arg-pro-progly-phe-ser-pro-phe-arg), and the 10-amino-acid peptide lysyl-bradykinin or kallidin (excellent reviews exist on kinins formation (Kaplan et al., 2002; Kaplan and Ghebrehiwet, 2010)). Bradykinin and kallidin are collectively referred to as kinins. 
Kinins participate in inflammatory processes by their ability to activate structural and inflammatory cells. Bradykinin has been shown to induce vasodilatation (Yamawaki et al., 1994) and vascular permeability (Ricciardolo et al., 1994a); it mediates the recruitment of inflammatory cells (Sato et al., 2000; Perron et al. 1999; Duchene et al. 2007), the production of nitric oxide (Ricciardolo et al., 2000) and the release of prostanoids (Li et al., 1998), tachykinins (Geppetti et al., 1995) and cytokines/chemokines (Koyama et al., 2000). In addition, bradykinin induces spasm of airway smooth muscle (Figini et al., 1996) with subsequent increase of airway resistance (Ricciardolo et al., 1994b). As illustrated in Fig. 1, bradykinin can also provoke stimulation of sensory neurons resulting in chronic hyperalgesia (Schuelert et al., 2015), alter the ion secretion by epithelial cells (Cozens et al.,1994) and modulate cell migration and tissue injury (Abraham et al., 2006) (Fig. 1). Bradykinin and kallidin display their biological effects upon binding and activation of their specific receptors $\mathrm{B}_{1}$ and $\mathrm{B}_{2}$. Bradykinin $\mathrm{B}_{1}$ receptor usually binds [des-Arg ${ }^{9}$ ]-bradykinin and [lys-desArg $^{9}$ ]-bradykinin, the latter is considered more selective (Leeb-Lundberg, 2005). Bradykinin $\mathrm{B}_{1}$ receptor is constitutively expressed in inflammatory, but not in residential, cells and it is regularly induced as a result of inflammation (Christiansen et al., 2002) in the presence of cytokines such as interleukin (IL)-1 and tumor necrosis factor (TNF)- $\alpha$ (Gurusamy et al., 2016). Bradykinin $\mathrm{B}_{2}$ receptors show high affinity for kallidin and bradykinin and are instead constitutively expressed on most cell types including those in the airways (Leeb-Lundberg, 2005). Both bradykinin receptors are $\mathrm{G}$ protein-coupled receptors. Their stimulation, via the activation of Gaq/11 family of heterotrimeric $\mathrm{G}$ proteins, induces a number of intracellular events related to inflammation (LeebLundberg, 2005; Ricciardolo et al., 2000, 1998).

\section{Kinin metabolism}

Metabolic degradation of kinins is a major mechanism for the regulation of their actions and virtually all tissues and biological fluids contain enzymes that are capable of degrading these 
peptides. Such enzymes include kininase I, also known as plasma carboxypeptidase N, and kininase II (Kaplan et al., 2002), the most important kinin-degrading enzymes in the endothelium of pulmonary vessels, which is identical to angiotensin-converting enzyme. Inhibition of this enzyme, with compounds such as captopril, results in a marked blockade of the metabolism of bradykinin. This enzyme has a higher affinity for bradykinin than for angiotensin I. Although the kininase IImediated metabolism may predominate in plasma and lungs, other enzymes such as aminopeptidase $\mathrm{M}$ and $\mathrm{P}$, and neutral endopeptidase, also called enkephalinase, are involved in the inactivation of bradykinin as well (Kaplan et al., 2002).

\section{Role of bradykinin in airway inflammation}

The activation of the kinin-kallikrein system plays a fundamental role in sustaining an acute inflammatory response by means of the synthesis of kinins. Their action on tissues is associated with vasodilation ("rubor and calor"), increased vascular permeability ("tumor"), pain (“dolor") and smooth muscle contraction ("function laesa") which are defined as "cardinal signs" by Aulus Cornelius Celsus and therefore implicated in the pathogenesis of acute inflammation. During the onset and progression of inflammation the kinin-kallikrein system activation liberates bradykinin, whose half-life is very short (30 s) due to metabolism by kininases. However, this is long enough to trigger intracellular signalling, initiated via the activation of bradykinin $\mathrm{B}_{2}$ receptors (Colman, 2006). Bradykinin, hence, initiates an acute inflammatory response and promotes the synthesis of other mediators, including prostaglandins, nitric oxide and tachykinins, modifying acute inflammatory response (Sainz et al., 2007) (Fig. 1).

Kinins are well known as mediators of bronchial hyperresponsiveness in asthma (Roisman et al., 1996). Different stimuli, including allergen exposure and viral infection are able to increase airway responsiveness associated with bradykinin, either in animal models (Ellis et al, 2004; Folkerts et al., 2000; Ricciardolo et al., 1994b) or in human asthmatics (Ricciardolo et al., 2001; Ricciardolo et al., 2012a). 
In asthmatic airways, kinins are able to provoke inflammatory oedema, mucus production, cough and smooth muscle contraction (cardinal signs of acute asthma) through the direct activation of bradykinin $\mathrm{B}_{2}$ receptor, neural cholinergic pathway, capsaicin-sensitive type $\mathrm{C}$ sensory nerve fibres (effect referred as 'neurogenic inflammation') (Geppetti et al., 1995) and the release of various inflammatory mediators acting on endothelial, epithelial and smooth muscle cells.

Some of these actions (direct activation of bradykinin $\mathrm{B}_{2}$ receptor on smooth muscle and stimulation of capsaicin-sensitive type $C$ sensory fibres and vagal nerves) are excitatory by provoking acute bronchoconstriction (Geppetti et al., 1995; Ricciardolo et al., 1994b) while, on the other hand, others (activation of epithelial cells through release of $\mathrm{PGE}_{2}$ and nitric oxide produced by constitutive nitric oxide synthase) are protective in terms of reducing bronchoconstriction itself (Figini et al., 1996; Ricciardolo et al., 1994c, 1996).

Another mechanism of action of bradykinin in the airways concerns its involvement in cough regulation. Inhaled bradykinin is able to induce cough: this effect is augmented by ACE inhibitors and seems to be dependent on capsaicin-sensitive non-myelinated bronchopulmonary C-fibers (Hewitt et al., 2016). Furthermore, bradykinin is able to upregulate the TRPV1 receptor sensitivity on $\mathrm{C}$ fibres (Lee et al 2010) provoking the release of tachykinins (substance $\mathrm{P}$ and neurokinin $\mathrm{A}$ ) (Geppetti et al., 1995) and, in addition, to induce the production of eicosanoids and prostaglandin in the airways (Lavorini et al., 2014; Hewitt et al., 2016) enhancing cough sensitivity (Lee et al 2010). Interestingly, a substantial increase of TRPV1-immunoreactive nerve profiles was found in the bronchial tissue of patients with chronic cough (Lee et al 2010).

The expression of bradykinin $\mathrm{B}_{2}$ receptor is regulated by bradykinin itself as reported in in vitro studies on epithelial cells (Ricciardolo et al., 2012b) and lung/bronchial fibroblasts (Sabatini et al., 2012, 2013). Bradykinin $B_{2}$ receptor expression is constitutively enhanced in bronchial fibroblasts from asthmatics compared to normal bronchial fibroblasts (Sabatini et al., 2013) and bradykinin itself increases the expression of bradykinin $\mathrm{B}_{2}$ receptor, particularly in asthmatic bronchial 
fibroblasts (Sabatini et al., 2013), showing a different cellular phenotype in relation to asthma (Th2driven) inflammatory milieu.

Bradykinin-induced bradykinin $\mathrm{B}_{2}$ receptor expression in human lung fibroblasts is suppressed by corticosteroid treatment (budesonide) (Sabatini et al., 2012), suggesting a potential role for transcription factors in the modulation of bradykinin $\mathrm{B}_{2}$ receptor expression. Bradykinin $\mathrm{B}_{2}$ receptor expression is increased in the bronchial mucosa of mild allergic asthmatics after allergen compared to diluent challenge and, in addition, in bronchial fibroblasts from asthmatics after exposure to the Th2 cytokines IL-4 and IL-13 compared to the untreated fibroblasts (Ricciardolo et al., 2016). The nuclear factor- $\mathrm{kB}(\mathrm{NF}-\mathrm{\kappa} \mathrm{B}) \mathrm{p} 65$ (Ser 276) inhibitor suppressed bradykinin $\mathrm{B}_{2}$ receptor upregulation induced by bradykinin and IL-4/IL-13 on bronchial fibroblasts in vitro, indicating that bradykinin $\mathrm{B}_{2}$ receptors protein expression is modulated by NF- $\mathrm{kB}$ pathway (Ricciardolo et al., 2016).

In human epithelial cells, the bradykinin $\mathrm{B}_{2}$ receptor mediates inflammatory signalling through activation of NF- $\kappa \mathrm{B}$ and an increase in cyclooxygenase-2 expression (Chen et al., 2004). Moreover, the activation of MAPK/NF- $\mathrm{BB}$ and their related signal pathways stimulates the production of cytokines (Hayashi et al., 2000). Of interest, the release of neutrophil-related cytokines like IL-6 and IL-8 could amplify the MAPK/NF- $\kappa \mathrm{B}$ signalling inducing airway kinin receptor upregulation as well (Bryborn et al., 2004; Newton et al., 2002; Zhang et al., 2007a). Elevated levels of bradykinin (Christiansen et al., 1992), IL-8 and human tissue kallikrein activation are reported in bronchoalveolar lavage fluids from allergic subjects and asthmatic patients with rhinovirus infection (Christiansen et al., 2008), which underlines the relationship between bradykinin and IL-8 and their possible role in virus-induced asthma exacerbation.

Less information is available on the role of bradykinin $\mathrm{B}_{1}$ receptor in asthma. The bradykinin $\mathrm{B} 1$ receptor antagonist R954 inhibited monocyte chemotactic protein-1 and interferon-gamma release, abolished TNF- $\alpha$ and IL-1 $\beta$ in bronchoalveolar lavage fluid in a mouse model of acute lung injury caused by lipopolysaccharide inhalation (Campanholle et al., 2010). Also an inhibitory effect of 
blocking bradykinin B1 receptor was observed in terms of eosinophil activation, proliferation and migration in a murine model of asthma (Vasquez-Pinto et al., 2010). The presence of bradykinin $\mathrm{B}_{1}$ and $\mathrm{B}_{2}$ receptors was confirmed on neutrophils and eosinophils from asthmatic and non-asthmatic subjects. A significantly greater protein expression of bradykinin $\mathrm{B}_{1}$ and $\mathrm{B}_{2}$ receptors was observed on eosinophils from asthmatic compared to non-asthmatic subjects (Bertram et al., 2007) (Bertram et al., 2009). A recent study showed the inhibitory effect of the bradykinin $B_{1}$ receptor antagonist on BAL cell recruitment (eosinophils, neutrophils, macrophages and lymphocytes) after allergen challenge in a mouse model demonstrating the involvement of bradykinin $\mathrm{B}_{1}$ in the processes regulating inflammatory cell migration towards the airway lumen in asthmatic mice (Gurusamy et al., 2016). Administration of a bradykinin $B_{2}$ receptor antagonist given before, during and 4 hours after antigen challenge significantly inhibited the late bronchial response, inflammatory mediators and the number of recruited neutrophils in an ovine model of asthma, suggesting that bradykinin $\mathrm{B}_{2}$ receptor selective antagonists may be potential drugs to reduce inflammatory cell infiltration in the late asthmatic response (Abraham et al., 2006).

A new role for bradykinin in modifying the cellular inflammatory response in the airways has recently been depicted. Bradykinin stimulates the release of the neutrophilic chemotactic agent IL8, via both bradykinin $\mathrm{B}_{2}$ and $\mathrm{B}_{1}$ receptors stimulation, in epithelial bronchial cells (BEAS2B). Furthermore, in BEAS2B cells co-cultured with human neutrophils, bradykinin increased myeloperoxidase release and 3-nitrotyrosine production suggesting that bradykinin induces “nitrosative stress", potentially mediated by IL-8 (Ricciardolo et al., 2012). "Nitrosative stress" is a pathogenic pathway involved in severe asthma (Fitzpatrick et al. 2009; Ricciardolo et al. 2006) and on the basis of the results obtained in our in vitro study using epithelial cells co-cultured with neutrophils we may speculate that bradykinin-induced "nitrosative stress" might contribute to chronic airway inflammation in neutrophilic-dependent (non-type 2) asthma. Bradykinin is also a mediator of hereditary and ACE-Inhibitor-induced angioedema (Riha et al 2017). Bradykinin-induced angioedema results from overproduction or reduced degradation of 
bradykinin (Misra et al., 2016). This rise of bradykinin concentration causes an increase in vascular permeability, vasodilation and oedema formation (Hsu et al., 2012). Icatibant, a bradykinin receptor competitive antagonist (Guo et al.,2017), has been tested in several clinical trials (Baş et al., 2015; Farkas et al., 2017; Sinert et al., 2017) reporting significant efficacy as a new therapeutic option in hereditary and ACE-Inhibitor-induced angioedema.

\section{Bradykinin in asthma}

Asthma is a chronic airway disease showing variable bronchial motor tone and airflow limitation (GINA Report 2017). Bronchial hyperresponsiveness, chronic inflammation and remodelling (structural alterations of airway wall) are major features of asthma and they are modulated, at least in part, by the epithelium layer (Ojiaku et al., 2017; Nair et al., 2017; Lambrecht and Hammad, 2012; Ricciardolo et al., 2003; Davies, 2009).

Different stimuli (allergen exposure, viral infection, cold air, various pollutants such as ozone and acidic molecules) may lead to acute airway inflammation, which triggers the production of proinflammatory mediators like TNF- $\alpha$, interleukins and, mostly, kinins (Christiansen et al., 1992; Folkerts et al., 2000; Yoshihara et al., 1996; Ricciardolo et al., 1999). These pro-inflammatory mediators can result in activation of intracellular signal pathways that induce upregulation of bradykinin receptors in the airways (Sabatini et al., 2013; Ricciardolo et al., 2016; Zhang et al., 2007). In allergic mild asthma the expression of bradykinin $B_{2}$ receptors is higher compared to control subjects (Ricciardolo et al., 2016). Subsequently, the kinin receptor upregulation and the epithelium dysfunction result in excessive bronchial hyperresponsiveness (Ricciardolo et al., 2001; Ricciardolo et al., 2003; Ricciardolo et al., 2016), which is a feature of uncontrolled asthma. Kinins are detected in bronchoaveolar lavage fluid from stable asthmatics (Christiansen et al., 1992). Furthermore, in atopic asthmatic patients, allergen exposure is associated with increased kinin concentrations in the epithelial lining fluid (Christiansen et al., 1992) and enhanced bronchial hyperresponsiveness to bradykinin (Ricciardolo et al., 2001), suggesting that anaphylactic response 
is able to amplify kinin formation and to upregulate kinin receptors. Both bradykinin receptor subtypes seem to contribute to allergen-induced bronchial hyperresponsiveness in rats (Huang et al., 1999). However, patients with asthma exhibit airway hyperresponsiveness to aerosolized bradykinin (bradykinin $\mathrm{B}_{2}$ receptor agonist), but not to des-Arg ${ }^{9}$-bradyknin (bradykinin $\mathrm{B}_{1}$ receptor agonist) indicating that, in the human model, bradykinin $\mathrm{B}_{1}$ receptor is not involved in acute bronchoconstriction. In healthy humans inhalation of bradykinin has little or no effect, but in asthmatics it produces significant bronchoconstriction associated with the perception of cardinal asthma symptoms (“chest tightness, cough, wheezing and dyspnoea”) resembling a natural asthma attack (Abraham et al., 2006).

Bradykinin is a weak constrictor in isolated human bronchi with epithelial integrity, while in vivo it is a potent bronchoconstrictor in asthmatic patients. This effect is due to the capability of bradykinin to activate cholinergic nerves (Reynolds et al., 1999), since bradykinin can stimulate airway parasympathetic ganglion neurons independently of sensory nerve activation, therefore providing an alternative mechanism for regulating airway parasympathetic tone (Kajekar and Myers, 2000).

On the other hand, epithelium-derived bronchoprotective factors such as nitric oxide are released by bradykinin (Figini et al., 1996; Ricciardolo et al., 2000) negatively modulating enhanced bronchial hyperresponsiveness in mild asthma (Ricciardolo et al., 1996, 2001) (Fig. 1). A further study also showed the impairment of the bronchoprotective nitric oxide on the bradykinin-induced airway hyperresponsiveness in moderate-to-severe asthma suggesting the loss of this protective mechanism in difficult-to-control patients (Ricciardolo et al, 1997). In addition, clinical studies confirmed the role of corticosteroids in decreasing bronchial hyperresponsiveness to bradykinin and the bradykinin receptor expression in eosinophils/neutrophils from asthmatics in association with the improvement of respiratory symptoms (Bertram et al., 2007, 2009, Reynolds et al., 2002) indicating that the bradykinin-induced effects on the asthmatic airways seem to be corticosteroid sensitive. In line with the latter studies, dexamethasone, a well-known anti-inflammatory corticosteroid drug, inhibited the kinin receptor upregulation and bronchial hyperresponsiveness to kinins in murine 
airways in vitro and the cigarette smoke-induced bronchial hyperresponsiveness in vivo (Zhang et al., 2004) (Lei et al., 2008) confirming a steroid sensitive modulation of kinin-induced airway responses. In a nice review, Zhang et al. pointed out that exposure to allergen, cigarette smoke or viral infection stimulated MAPK/NF- $\mathrm{B}$ pathway promoting the gene upregulation of bradykinin receptors and subsequently increased bronchial responsiveness. These environmental risk factors result in the synthesis of pro-inflammatory mediators, such as TNF- $\alpha$ and ILs, that activate intracellular MAPK and NF-אB (Zhang et al., 2013).

Incubation of murine airway segments for $24 \mathrm{~h}$ in medium significantly increased bradykinin $\mathrm{B}_{1}$ receptors and cyclooxygenase- 2 expression which were significantly decreased by dexamethasone. (Xu and Cardell, 2014) Interestingly, incubation with nicotine significantly suppressed the cyclooxygenase-2 mediated and epithelium-dependent relaxations to bradykinin in organ culture (not reversed by dexamethasone) and, additionally, nicotine long-term exposure enhanced murine airway contractile responses to kinins suggesting that the nicotine-potentiating contractile effects in the airways might explain the mechanism of corticosteroid resistance in smoking asthma (Xu et al., 2010; Xu and Cardell, 2014).

Tabet et al. demonstrated a relationship between bradykinin-induced relaxation by means of hyperpolarization in human bronchi and the synthesis of the bronchorelaxing/hyperpolarizing factors epoxyeicosatrienoic acids produced by the endogenous CYP450 epoxygenase indicating a role for these arachidonic acid metabolites in hyperpolarization, via the large conductance $\mathrm{Ca}^{2+}$ sensitive $\mathrm{K}^{+}$channel, of airway smooth muscle cells induced by bradykinin (Tabet et al., 2013). Finally, we would like to point out that a main risk factor for asthma inception and/or worsening is chronic rhinitis (Brozek et al., 2017). Bradykinin- or allergen-induced nasal blockage and plasma extravasation are mediated by bradykinin $\mathrm{B}_{2}$ receptors in the human nasal airway (Shirasaki et al., 2009; Thornton et al., 2013) and in animal models (Ricciardolo et al., 1994a; Valenti et al., 2008). Moreover, in allergic rhinitis, the expression of bradykinin $B_{1}$ receptor mRNA was significantly higher than in healthy subjects. Nasal allergen challenge increased bradykinin $\mathrm{B}_{1}$ receptor mRNA 
expression in subjects with allergic rhinitis (Christiansen et al., 2002) indicating that both kinin receptors are involved in vascular responses of chronic rhinitis.

\section{6. $B_{1}$ and $B_{2}$ bradykinin receptor antagonists}

In normal human airways there is minimal expression of constitutive bradykinin $\mathrm{B}_{1}$ receptors in residential cells; this implies that the bronchoconstrictor response is mediated by bradykinin $\mathrm{B}_{2}$ receptors (Abraham et al 2006; Ricciardolo et al., 2013).

Activation of bradykinin $\mathrm{B}_{2}$ receptor is able to induce bronchoconstriction, vascular permeability, mucus secretion and cholinergic/sensory nerve stimulation. To counteract these effects several studies developed peptide and non-peptide receptor antagonists as potential therapeutic agents (Abraham et al 2006).

The class of peptide $\mathrm{B}_{2}$ receptor antagonist is subdivided in three generation: the first is represented by NPC349 and later NPC567 and NPC17731: these are selective $\mathrm{B}_{2}$ receptor antagonist but with a reduced biological activity because of their susceptibility to enzymatic cleavage; the second generation of peptide antagonists is more potent and selective than the previous generation and it is resistant to peptidases: major representative is HOE 140 (Icatibant); the third generation is represented by B-9430, a longer acting peptide antagonist with a dual interaction with both receptors (Abraham et al 2006).

Non-peptide antagonists were extensively studied: the first one WIN64338 had low affinity for human bradykinin $\mathrm{B}_{2}$ receptor, then FR173657 and FR184280 seem to be more effective and lastly MEN16132 that is a selective $\mathrm{B}_{2}$ receptor antagonist with good efficacy in inhibiting the bradykinin-induced bronchoconstriction in guinea pigs airways (Abraham et al 2006). Peptide antagonists, including Icatibant, were widely studied both in animal models and in humans showing a potential effect in blocking bradykinin-induced bronchocostrition (Leeb-Lundberg 2005). More than 20 years ago a double blinded, randomized, placebo-controlled phase II study has been performed in order to investigate the efficacy of the $\mathrm{B}_{2}$ bradykinin receptor antagonist Icatibant on 
moderate to severe asthmatics (Akbary et al., 1996). Four weeks treatment of nebulized Icatibant (t.i.d. 900 p,g or $3000 \mathrm{mcg}$ ) led to a dose-dependent improvement in pulmonary function tests (PFTs) but no clinically relevant improvement in global symptom score was noted compared to placebo. During the study it has not been shown an acute bronchodilator effect but a gradually (week by week) increase of functional parameters until the end of active treatment suggesting a role as anti-inflammatory drug. No other trials with Icatibant have been performed and currently it would be interesting to test its effect in selected population of asthmatics on the basis of phenotypes.

Non-peptide receptor antagonists, such as MEN16132 (Valenti et al 2008), seems to be more effective than peptide antagonists in cell cultures and in guinea pigs airways, but there are still too little data available on their efficacy in humans.

Activation and upregulation of bradykinin $\mathrm{B}_{1}$ receptor in the airways of asthmatics is supported by the fact that its expression could be induced by several proinflammatory cytokines. Studies on $\mathrm{B}_{1}$ receptor antagonists, R-715 (El-Kady et al., 2016) and BI113823 (Gurusamy et al., 2016), were conducted mainly on allergic airway inflammation. The former demonstrated a decrease in bronchial leukocyte infiltration, albumin, IL-1 $\beta$ and serum OVA-specific IgE level and suppressed both bronchial cyclooxygenase-2 and inducible nitric oxide synthase expression (El-Kady et al., 2016). The latter reduced inflammatory cell infiltration, cytokine production and reduced mucus expression (Gurusamy et al., 2016). Also these B1 receptor antagonists, as well as non-peptide $\mathrm{B}_{2}$ receptor antagonists, were tested only in animal models.

\section{Bradykinin and matrix-related airway remodelling}

In asthma, the inflammatory milieu generates a state of abnormal activation of epithelial cells with release of growth factors, particularly TGF- $\beta$ (Brightling et al., 2012; Ojiaku et al., 2017).

Consequently, the latter stimulates mesenchymal cell proliferation and promotes differentiation of fibroblasts into myofibroblasts which express alpha-smooth muscle actin and secrete increased 
amount of extracellular matrix components, such as type I collagen (Al-Muhsen et al., 2011; Ojiaku et al., 2017). This cascade, known as the "epithelial mesenchymal trophic unit", probably drives the remodelling of the asthmatic airways (Davies et al., 2003). TGF- $\beta$ increases intracellular calcium mobilization in human airway smooth muscle cells, therefore enhancing airway smooth muscle responsiveness to bradykinin (Kim et al., 2005). Moreover, TGF- $\beta$ modulates the responsiveness to bradykinin by increasing mRNA and protein expression of bradykinin $\mathrm{B}_{2}$ receptor in human airway smooth muscle cells (Kim et al., 2005). In an in vitro model of embryonic kidney cells, bradykinin $\mathrm{B}_{2}$ receptor-mediated Gaq/11 activation was involved in cell proliferation via the mitogen-activated protein kinases (MAPK) activation, particularly p38 and extracellular-regulated kinase (ERK)1/2, and/or cross-talk with EGF-receptor (Zimmerman et al., 2011). Investigations of intracellular molecular signal mechanisms showed that activation of MAPK/NF- $\kappa \mathrm{B}$ signal pathways regulates cellular events like differentiation, proliferation, apoptosis and production of pro-inflammatory mediators as well as expression of GPCR in airways (Damera et al., 2012; Gerthoffer and Singer, 2003). In asthmatic patients, there are significant levels of phosphorylated ERK1/2 and p38 MAPK that correlate to the severity of airway disease ( Liu et al., 2008; Vallese et al., 2015). Bradykinin induced the differentiation of normal human lung fibroblasts into myofibroblasts ( $\alpha$-smooth muscle actin $[\alpha-S M A]^{+}$cells) via bradykinin $B_{2}$ receptor activation (Vancheri et al., 2005). We showed that bradykinin at low concentration (in the range of picomolar) induced cell proliferation in human bronchial fibroblasts from asthmatics and healthy controls, whereas at higher concentration $\left(10^{-9}\right.$ $10^{-6} \mathrm{M}$ ) bradykinin induced myofibroblast differentiation and blocks proliferation (Sabatini et al., 2013). In addition, the bradykinin-induced proliferation in asthmatic/normal fibroblast was dependent on metalloproteinase cleavage of the EGFR ligand precursors and EGFR transactivation, upon the bradykinin $\mathrm{B}_{2}$ receptor-ligand interaction, through activation of the G-protein cascade. The subsequent phosphorylation of ERK1/2 was involved in the regulation of cell proliferation in response (Sabatini et al., 2013) (Fig. 2). On the other hand, the p38-MAPK pathway mediated bradykinin-induced human bronchial fibroblast differentiation and polymerization of $\alpha-\mathrm{SMA}^{+}$fibres 
(Sabatini et al., 2013). These experimental observations, showing that different concentrations of bradykinin trigger various cellular responses, suggest a temporal sequence of fibroblast driven airway remodelling, able to produce a progressive reduction in the airway lumen diameter in chronic asthma. Bradykinin triggered a concentration-dependent fibroblast gel contraction in conjunction with $\alpha$-SMA overexpression, a phenomenon inhibited in $\alpha$-SMA-siRNA-treated cells (Petecchia et al., 2010). In addition, bradykinin increased $\mathrm{F}$-actin ${ }^{+}$stress fibres polymerization and intracellular calcium levels, with phosphorylation of the myosin light-chain. All these data indicate that bradykinin-induced differentiation of fibroblasts into myofibroblasts and their contraction is mediated via bradykinin $\mathrm{B}_{2}$ receptor activation involving $\mathrm{Ca}^{2+}$-calmodulin phosphorylation of the myosin light-chain dependent pathway (Petecchia et al., 2010) (Fig.2).

\section{Bradykinin and vascular airway remodelling}

Angiogenesis, a process of formation of new capillaries, from existing microvessels involves several steps beginning with localised degradation of the basement membrane of the existing vessels. Endothelial cells detach from the basement membrane and migrate into the perivascular space where they proliferate. The new endothelial cells then form tube-like structures that eventually join and form new capillaries. Different promoting or inhibiting factors regulate this process. VEGF stimulates endothelial cell migration and proliferation and is widely expressed in highly vascularised organs such as lungs. Angiogenin is implicated as a mitogen for vascular endothelial cells and induces vascular endothelial cell proliferation, migration and tubule formation. The kinin-kallikrein system is also involved in angiogenesis; in particular high molecular weight kininogens, the residue derived from high molecular weight kininogens hydrolysis to form bradykinin, is an angiogenesis inhibitor able to block endothelial cell proliferation and migration. Moreover, bradykinin promotes angiogenesis by upregulation of bFGF or VEGF, by regulation of vascular permeability, by stimulation of cell proliferation through bradykinin $\mathrm{B}_{2}$ receptor and by endothelial-nitric oxide synthase activation in endothelial cells (Colman, 2006). Angiogenesis is 
recognised as a fundamental event in the development of airway remodelling that leads to irreversible obstruction (Postma and Timens, 2006). Proteins involved in angiogenesis, like VEGF and angiogenin are increased in asthma, and are associated with vascular remodelling (Hashimoto et al., 2005; Hoshino et al., 2001). We demonstrated that the VEGF-A ${ }^{+}$cell counts in the bronchial mucosa (lamina propria) of old and young asthmatics were higher than in age matched nonsmoking controls, and that endothelial $\mathrm{CD}_{3} 1^{+}$, angiogenin ${ }^{+}$, bradykinin $\mathrm{B}_{2}$ receptor ${ }^{+}$and bradykinin $\mathrm{B}_{1}$ receptor $^{+}$cell numbers in the lamina propria were higher in old asthmatics than in age matched non-smoking controls, smoking controls and COPD patients (Ricciardolo et al., 2013). Furthermore, angiogenin ${ }^{+}$cells were significantly increased in patients with severe asthma compared with patients with mild asthma, in conjunction with a higher number of $\mathrm{CD} 4^{+}$cells, neutrophils and eosinophils. All of these data suggest that angiogenin-related vascular remodelling is a feature of severe asthma and asthma in the elderly (Ricciardolo et al., 2013). In asthmatic patients, the number of bradykinin $\mathrm{B}_{2}$ receptor ${ }^{+}$cells is positively related to the number of bradykinin $\mathrm{B}_{1}$ receptor ${ }^{+}$, angiogenin $^{+}$and $\mathrm{CD} 31^{+}$cells, indicating a functional interplay between the kinin system and neoangiogenesis in asthma (Ricciardolo et al., 2013). In addition, only the numbers of angiogenin ${ }^{+}$ cells were negatively related to forced expiratory volume $1 \mathrm{~s}$ which confirms a role for angiogenin in developing progressive airflow limitation and fixed airway obstruction in chronic asthma. Interestingly, the number of neutrophils in the lamina propria of asthmatic bronchial biopsies was related to the number of $\mathrm{CD} 31^{+}$cells and $\mathrm{B}_{2}$ receptor ${ }^{+}$cells (Fig. 3) suggesting that neutrophilic asthma is associated with bradykinin $\mathrm{B}_{2}$ receptor expression and increased vascularization in asthmatic airways.

Confocal microscopy showed that $\mathrm{CD} 31^{+}$cells (marker of endothelial cells) of capillary vessels in the lamina propria of asthmatic patients also co-express bradykinin $\mathrm{B}_{2}$ receptors, demonstrating a role for bradykinin $\mathrm{B}_{2}$ receptors in airway microvessel function (Ricciardolo et al., 2013). In addition, the large majority of cells in the lamina propria of asthmatics were fibroblasts $\left(5 \mathrm{~B}^{+}\right)$coexpressing bradykinin $\mathrm{B}_{2}$ receptors (72\%), VEGF-A (87\%) and angiogenin (80.5\%). In an in vitro 
study, bradykinin induces a significant increase of VEGF and angiogenin release in human asthmatic bronchial fibroblasts, and in particular angiogenin release was relatively higher in comparison with human bronchial fibroblast from COPD patients (Ricciardolo et al., 2013). These data infer the involvement of bradykinin receptors in modulating bronchial vascular remodelling in asthma, via fibroblasts activation and subsequent release of vascular growth factors (Fig. 1).

\section{Conclusion}

Kinins and their receptors are detected in the respiratory tract and could be highly produced and expressed under specific pathophysiological conditions in asthma. For a long time, bradykinin has been considered a mediator of acute responses in asthma (mainly as a mediator of neurogenic inflammation and airway responsiveness), but most recent evidence sheds light on additional longterm effects of bradykinin in mesenchymal and endothelial cells activating downstream cascades (including release of growth factors and stimulation of MAPK/EGFR) involved in the chronicity and severity of asthma such as matrix- and vascular-related airway remodelling.

Bradykinin and their receptors are highly involved in allergen-induced responses and it seems that bradykinin $\mathrm{B}_{2}$ receptor expression and bradykinin-related activities are specifically modulated by Th2 responses (due to IL-4/IL-13) in asthmatic fibroblasts pointing to a role in the remodelling process related to allergic severe asthma. On the other hand, also smoke- and virus-induced asthma showed up-regulation of bradykinin receptors. The latter seems to be associated with neutrophildependent inflammatory process with a relative steroid resistance ("neutrophilic asthma").

Future studies are warranted in order to focus on the role of bradykinin and related receptors in specific asthma phenotypes (type 2 or non-type 2) (Wenzel et al., 2012) where the bradykinin pathway should be involved as molecular targets (personalized therapy). Actually, therapeutic strategies might be directed against the synthesis of kinins or the expression of bradykinin receptors 
in order to modulate one of the most important clinically relevant features of asthma, namely airway remodelling. 


\section{Acknowledgement}

The authors thank Drs. Federica Sabatini and Michela Silvestri for their helpful contribution to the figures. 


\section{Legend to the figures}

\section{Fig. 1: Effects of bradykinin on asthmatic airways.}

In airway epithelial cells bradykinin stimulates the release of bronchorelaxing factors $\mathrm{PGE}_{2}$ and nitric oxide, the mucus secretion from human submucosal glands and the ion transport. Bradykinin is a potent inducer of airway microvascular leakage and vascular permeability and causes prolonged leakage at all airway levels. Moreover it has direct effects on the recruitment and activation of inflammatory cells. Upon stimulation of bradykinin receptors, fibroblasts activation provokes the release of vascular growth factors (VEGF and angiogenin) able to modulate bronchial vascular remodelling in asthma. In airway smooth muscle bradykinin induces bronchoconstriction via direct stimulation of its receptors and via indirect neural activation (cholinergic nerves and C-fibre sensory nerves); nevertheless, epithelium-derived $\mathrm{PGE}_{2}$ and nitric oxide reduce excessive bronchoconstriction in asthma.

\section{Fig. 2: Bradykinin-induced intracellular pathways in human bronchial fibroblasts.}

Bradykinin $\mathrm{B}_{2}$ receptor coordinates human bronchial fibroblast proliferation and differentiation.

These effects on bronchial fibroblast are due to activation of bradykinin $\mathrm{B}_{2}$ receptor and to subsequent stimulation of different MAPK/ERK pathways with the involvement of the metalloproteinase/EGF receptor signalling cascade.

Low concentration of bradykinin is able to induce fibroblast proliferation via phosphorylation of p38 and ERK1/2. The latter is phosphorylated through metalloprotease-mediated cleavage of the EGF receptor ligand precursor. Higher concentration of bradykinin provokes the differentiation from fibroblast to myofibroblast via p38 pathway only. Myofibroblast differentiation is characterized by $\alpha$-SMA polymerization in $\mathrm{F}_{-} \operatorname{actin}^{+}$stress fibres and increased intracellular calcium levels in conjunction with phosphorylation of myosin light-chain. The organization in cytoskeletal 
filaments of $\alpha$-SMA and F-actin ${ }^{+}$stress fibres reflects the plasticity of activated myofibroblasts promoting contractile behaviour.

Fig. 3: Correlations between the number of neutrophils and $\mathrm{CD}^{+} 1^{+}$cells or bradykinin $\mathrm{B}_{2}$ receptor $^{+}$cells in the lamina propria of asthmatic bronchial biopsies.

Panel A: correlation between number of neutrophils and CD31 ${ }^{+}$cells in the lamina propria of bronchial biopsies in asthmatics $\left(\right.$ cell $\left./ \mathrm{mm}^{2}\right) \mathrm{r}_{\mathrm{s}}=0,47, \mathrm{P}=0,02$

Panel B: correlation between number of neutrophils and $\mathrm{B}_{2}$ receptor ${ }^{+}$cells in the lamina propria of bronchial biopsies in asthmatics $\left(\right.$ cell $\left./ \mathrm{mm}^{2}\right) \mathrm{r}_{\mathrm{s}}=0,44, \mathrm{P}=0,007$

These data are derived from: Ricciardolo et al. Expression of vascular remodelling markers in relation to bradykinin receptors in asthma and COPD. Thorax. 2013 Sep;68(9):803-11. doi:10.1136/thoraxjnl-2012-202741 (graphs unpublished). 


\section{References}

Abraham, W.M., Scuri, M., Farmer, S.G., 2006. Peptide and non-peptide bradykinin receptor antagonists: role in allergic airway disease. Eur. J. Pharmacol. 533, 215-21. doi:10.1016/j.ejphar.2005.12.071

Akbary AM, Wirth KJ, Schölkens BA, 1996. Efficacy and tolerability of Icatibant (Hoe 140) in patients with moderately severe chronic bronchial asthma. Immunopharmacology. 33:238-42.

Al-Muhsen, S., Johnson, J.R., Hamid, Q., 2011. Remodeling in asthma. J. Allergy Clin.Immunol. 128:451-62; quiz 463-4. doi: 10.1016/j.jaci.2011.04.047.

Baş M, Hoffmann TK, Kojda G, 2015. Icatibant in ACE-inhibitor-induced angioedema. N Engl J Med. 372:1867-8. doi: 10.1056/NEJMc1503671.

Bertram, C., Misso, N.L., Fogel-Petrovic, M., Figueroa, C., Thompson, P.J., Bhoola, K.D., 2007. Comparison of kinin $\mathrm{B}(1)$ and $\mathrm{B}(2)$ receptor expression in neutrophils of asthmatic and non-asthmatic subjects. Int. Immunopharmacol. 7, 1862-8. doi:10.1016/j.intimp.2007.07.012

Bertram, C.M., Misso, N.L., Fogel-Petrovic, M., Figueroa, C.D., Foster, P.S., Thompson, P.J., Bhoola, K.D., 2009. Expression of kinin receptors on eosinophils: comparison of asthmatic patients and healthy subjects. J. Leukoc. Biol. 85, 544-52. doi:10.1189/jlb.0508283.

Brightling, C.E., Gupta, S., Gonem, S., Siddiqui, S., 2012. Lung damage and airway remodelling in severe asthma. Clin Exp Allergy. 42, 638-49. doi: 10.1111/j.1365-2222.2011.03917.x.

Brożek JL, Bousquet J, Agache I, Agarwal A, Bachert C, Bosnic-Anticevich S, Brignardello-Petersen R, Canonica GW, Casale T, Chavannes NH, Correia de Sousa J, Cruz AA, Cuello-Garcia CA, Demoly P, Dykewicz M, Etxeandia-Ikobaltzeta I, Florez ID, Fokkens W, Fonseca J, Hellings PW, Klimek L, Kowalski S, Kuna P, Laisaar KT, Larenas-Linnemann DE, Lødrup Carlsen KC, Manning PJ, Meltzer E, Mullol J, Muraro A, O'Hehir R, Ohta K, Panzner P, Papadopoulos N, Park HS, Passalacqua G, Pawankar R, Price D, Riva JJ, Roldán Y, Ryan D, Sadeghirad B, Samolinski B, Schmid-Grendelmeier P, Sheikh A, Togias A, Valero A, Valiulis A, Valovirta E, Ventresca M, Wallace D, Waserman S, Wickman M, Wiercioch W, Yepes-Nuñez JJ, Zhang L, Zhang Y, Zidarn M, Zuberbier T, Schünemann HJ, 2017. Allergic Rhinitis and its Impact on Asthma (ARIA) guidelines-2016 revision. J Allergy Clin Immunol.; 140:950-958. doi: 10.1016/j.jaci.2017.03.050.

Bryborn, M., Adner, M., Cardell, L.-O., 2004. Interleukin-4 increases murine airway response to kinins, via upregulation of bradykinin B1-receptors and altered signalling along mitogen-activated protein kinase pathways. Clin. Exp. Allergy 34, 1291-8. doi:10.1111/j.1365-2222.2004.02031.x 
Campanholle, G., Landgraf, R.G., Borducchi, E., Semedo, P., Wang, P.H.M., Amano, M.T., Russo, M., Pacheco-Silva, A., Jancar, S., Camara, N.O.S., 2010. Bradykinin inducible receptor is essential to lipopolysaccharide-induced acute lung injury in mice. Eur. J. Pharmacol. 634, 132-7. doi:10.1016/j.ejphar.2010.02.002

Chen, B.-C., Yu, C.-C., Lei, H.-C., Chang, M.-S., Hsu, M.-J., Huang, C.-L., Chen, M.-C., Sheu, J.-R., Chen, T.-F., Chen, T.-L., Inoue, H., Lin, C.-H., 2004. Bradykinin B2 receptor mediates NF-kappaB activation and cyclooxygenase-2 expression via the Ras/Raf-1/ERK pathway in human airway epithelial cells. J. Immunol. Baltim. Md 1950 173, 5219-28.

Christiansen, S.C., Eddleston, J., Woessner, K.M., Chambers, S.S., Ye, R., Pan, Z.K., Zuraw, Christiansen, S.C., Proud, D., Sarnoff, R.B., Juergens, U., Cochrane, C.G., Zuraw, B.L., 1992. Elevation of tissue kallikrein and kinin in the airways of asthmatic subjects after endobronchial allergen challenge. Am. Rev. Respir. Dis. 145, 900-5. doi:10.1164/ajrccm/145.4_Pt_1.900

Christiansen, S.C., Eddleston, J., Woessner, K.M., Chambers, S.S., Ye, R., Pan, Z.K., Zuraw, B.L., 2002. Up-regulation of functional kinin B1 receptors in allergic airway inflammation. J. Immunol. 169, 2054-60.

Christiansen, S.C., Eddleston, J., Bengtson, S.H., Jenkins, G.R., Sarnoff, R.B., Turner, R.B., Gwaltney, J.M., Zuraw, B.L., 2008. Experimental rhinovirus infection increases human tissue kallikrein activation in allergic subjects. Int. Arch. Allergy Immunol. 147, 299-304. doi:10.1159/000144037

Colman, R.W., 2006. Regulation of angiogenesis by the kallikrein-kinin system. Curr. Pharm. Des. 12, $2599-607$.

Cozens, A.L., Yezzi, M.J., Kunzelmann, K., Ohrui, T., Chin, L., Eng, K., Finkbeiner, W.E., Widdicombe, J.H., Gruenert, D.C., 1994. CFTR expression and chloride secretion in polarized immortal human bronchial epithelial cells. Am J Respir Cell Mol Biol.10:38-47.

Damera, G., Druey, K.M., Cooper, P.R., Krymskaya, V.P., Soberman, R.J., Amrani, Y., Hoshi, T., Brightling, C.E., Panettieri, R.A., 2012. An RGS4-mediated phenotypic switch of bronchial smooth muscle cells promotes fixed airway obstruction in asthma. PloS One 7, e28504. doi:10.1371/journal.pone.0028504

Davies, D.E., Wicks, J., Powell, R.M., Puddicombe, S.M., Holgate, S.T., 2003. Airway remodeling in asthma: new insights. J. Allergy Clin. Immunol. 111, 215-25; quiz 226.

Davies, D.E., 2009. The role of the epithelium in airway remodeling in asthma. Proc. Am. Thorac. Soc. 6, 678-82. doi: 10.1513/pats.200907-067DP

Duchene J, Lecomte F, Ahmed S, Cayla C, Pesquero J, Bader M, Perretti M, Ahluwalia A, 2007. A novel inflammatory pathway involved in leukocyte recruitment: role for the kinin B1 receptor and the chemokine CXCL5. J Immunol. 179, 4849-56. 
El-Kady MM, Girgis ZI, Abd El-Rasheed EA, Shaker O, Attallah MI, Soliman AA, 2016. Role of selective blocking of bradykinin receptor subtypes in attenuating allergic airway inflammation in guinea pigs. Eur. J. Pharmacol. 788, 152-159. doi: 10.1016/j.ejphar.2016.06.024.

Ellis, K.M., Cannet, C., Mazzoni, L., Frossard, J.R. 2004. Airway hyperresponsiveness to bradykinin induced by allergen challenge in actively sensitised Brown Norway rats. Naunyn Schmiedebergs Arch. Pharmacol. $369,166-78$.

Farkas H, Reshef A, Aberer W, Caballero T, McCarthy L, Hao J, Nothaft W, Schranz J, Bernstein JA, Li HH, 2017. Treatment Effect and Safety of Icatibant in Pediatric Patients with Hereditary Angioedema. J Allergy Clin Immunol Pract. 5:1671-1678.e2. doi: 10.1016/j.jaip.2017.04.010.

Figini, M., Ricciardolo, F.L., Javdan, P., Nijkamp, F.P., Emanueli, C., Pradelles, P., Folkerts, G., Geppetti, P., 1996. Evidence that epithelium-derived relaxing factor released by bradykinin in the guinea pig trachea is nitric oxide. Am. J. Respir. Crit. Care Med. 153, 918-23. doi:10.1164/ajrccm.153.3.8630573

Fitzpatrick AM, Brown LA, Holguin F, Teague WG; National Institutes of Health/National Heart, Lung, and Blood Institute Severe Asthma Research Program, 2009. Levels of nitric oxide oxidation products are increased in the epithelial lining fluid of children with persistent asthma. J Allergy Clin Immunol. 124:990-6.e1-9. doi: 10.1016/j.jaci.2009.08.039.

Folkerts, G., Vlieger, J.W., de Vries, A., Faas, S., van Der Linde, H., Engels, F., de Jong, J.C., Verheyen, F.A., Van Heuven-Nolsen, D., Nijkamp, F.P., 2000. Virus- and bradykinin-induced airway hyperresponsiveness in guinea pigs. Am. J. Respir. Crit. Care Med. 161, 1666-71. doi:10.1164/ajrccm.161.5.9710002

Geppetti, P., Bertrand, C., Ricciardolo, F.L., Nadel, J.A., Ricciardolo, F.M., 1995. New aspects on the role of kinins in neurogenic inflammation. Can. J. Physiol. Pharmacol. 73, 843-847.

Gerthoffer, W.T., Singer, C.A., 2003. MAPK regulation of gene expression in airway smooth muscle. Respir. Physiol. Neurobiol. 137, 237-50.

GINA updated 2017: Global Strategy for Asthma Management and Prevention, 2017. Global Initiative for Asthma. www.ginasthma.org.

Guo C, Settipane RA, 2016. Clinical presentation, pathophysiology, diagnosis, and treatment of acquired and hereditary angioedema: Exploring state-of-the-arttherapies in RI. R I Med J (2013). 99:41-4.

Gurusamy, M., Nasseri, S., Lee, H., Jung, B., Lee, D., Khang, G., Abraham, W.M., Doods, H., Wu, D., 2016. Kinin B1 receptor antagonist BI113823 reduces allergen-induced airway inflammation and mucus secretion in mice. Pharmacol. Res. 104, 132-139. doi:10.1016/j.phrs.2015.12.017 
Hashimoto, M., Tanaka, H., Abe, S., 2005. Quantitative analysis of bronchial wall vascularity in the medium and small airways of patients with asthma and COPD. Chest 127, 965-72. doi:10.1378/chest.127.3.965

Hayashi, R., Yamashita, N., Matsui, S., Fujita, T., Araya, J., Sassa, K., Arai, N., Yoshida, Y., Kashii, T., Maruyama, M., Sugiyama, E., Kobayashi, M., 2000. Bradykinin stimulates IL-6 and IL-8 production by human lung fibroblasts through ERK- and p38 MAPK-dependent mechanisms. Eur Respir J 16, 452-458.

Hewitt MM, Adams G Jr, Mazzone SB, Mori N, Yu L, Canning BJ. Pharmacology of Bradykinin-Evoked Coughing in Guinea Pigs. J Pharmacol Exp Ther. 2016 Jun;357(3):620-8. doi: 10.1124/jpet.115.230383.

Hoshino, M., Takahashi, M., Aoike, N., 2001. Expression of vascular endothelial growth factor, basic fibroblast growth factor, and angiogenin immunoreactivity in asthmatic airways and its relationship to angiogenesis. J. Allergy Clin. Immunol. 107, 295-301. doi:10.1067/mai.2001.111928

Huang, T.J., Haddad, E.B., Fox, A.J., Salmon, M., Jones, C., Burgess, G., Chung, K.F., 1999. Contribution of bradykinin $\mathrm{B}(1)$ and $\mathrm{B}(2)$ receptors in allergen-induced bronchial hyperresponsiveness. Am. J. Respir. Crit. Care Med. 160, 1717-23. doi:10.1164/ajrccm.160.5.9901029

Kajekar, R., Myers, A.C., 2000. Effect of bradykinin on membrane properties of guinea pig bronchial parasympathetic ganglion neurons. Am. J. Physiol. Lung Cell. Mol. Physiol. 278, L485-91.

Kaplan, A.P., Joseph, K., Silverberg, M., 2002. Pathways for bradykinin formation and inflammatory disease. J. Allergy Clin. Immunol. 109, 195-209.

Kaplan, A.P., Ghebrehiwet, B., 2010. The plasma bradykinin-forming pathways and its interrelationships with complement. Mol. Immunol. 47, 2161-2169. doi:10.1016/j.molimm.2010.05.010

Kashuba, E., Bailey, J., Allsup, D., Cawkwell, L., 2013. The kinin-kallikrein system: physiological roles, pathophysiology and its relationship to cancer biomarkers. Biomark. Biochem. Indic. Expo. Response Susceptibility Chem. 18, 279-96. doi:10.3109/1354750X.2013.787544

Kim, J.H., Jain, D., Tliba, O., Yang, B., Jester, W.F., Panettieri, R.A., Amrani, Y., Puré, E., 2005. TGF-beta potentiates airway smooth muscle responsiveness to bradykinin. Am. J. Physiol. Lung Cell. Mol. Physiol. 289, L511-20. doi:10.1152/ajplung.00027.2005

Koyama, S., Sato, E., Numanami, H., Kubo, K., Nagai, S., Izumi, T., 2000. Bradykinin stimulates lung fibroblasts to release neutrophil and monocyte chemotactic activity. Am. J. Respir. Cell Mol. Biol. 22, 75-84. doi:10.1165/ajrcmb.22.1.3752

Lambrecht, B.N., Hammad, H., 2012. The airway epithelium in asthma. Nat. Med. 18, 684-92. doi:10.1038/nm.2737 
Lavorini, F., Chellini, E., Innocenti, M., Campi, G., Egan, C.G., Mogavero, S., Fontana, G.A., 2014. A crossover randomized comparative study of zofenopril and ramipril on cough reflex and airway inflammation in healthy volunteers. Cough. 10:7. doi: 10.1186/s12997-014-0007-5.

Lee, L.Y., Ni, D., Hayes, D. Jr., Lin, R.L., 2011. TRPV1 as a cough sensor and its temperature-sensitive properties. Pulm Pharmacol Ther. 24:280-5. doi:10.1016/j.pupt.2010.12.003.

Leeb-Lundberg, L.M.F., Marceau, F., Muller-Esterl, W., Pettibone, D.J., Zuraw, B.L., 2005. International Union of Pharmacology. XLV. Classification of the Kinin Receptor Family: from Molecular Mechanisms to Pathophysiological Consequences. Pharmacol. Rev. 57, 27-77. doi:10.1124/pr.57.1.2

Lei, Y., Cao, Y.-X., Xu, C.-B., Zhang, Y., 2008. The Raf-1 inhibitor GW5074 and dexamethasone suppress sidestream smoke-induced airway hyperresponsiveness in mice. Respir. Res. 9, 71. doi:10.1186/1465-9921-9-71

Li, L., Vaali, K., Paakkari, I., Vapaatalo, H., 1998. Involvement of bradykinin B1 and B2 receptors in relaxation of mouse isolated trachea. Br. J. Pharmacol. 123, 1337-1342. doi:10.1038/sj.bjp.0701741

Liu, W., Liang, Q., Balzar, S., Wenzel, S., Gorska, M., Alam, R., 2008. Cell-specific activation profile of extracellular signal-regulated kinase 1/2, Jun N-terminal kinase, and p38 mitogen-activated protei.n kinases in asthmatic airways. J. Allergy Clin. Immunol. 121, 893-902.e2. doi:10.1016/j.jaci.2008.02.004.

MacPherson, J.C., Comhair, S.A.A., Erzurum, S.C., Klein, D.F., Lipscomb, M.F., Kavuru, M.S., Samoszuk, M.K., Hazen, S.L., 2001. Eosinophils are a major source of nitric oxide-derived oxidants in severe asthma: chracterization of pathways available to eosinophils for generating reactive nitrogen species. J. Immunol. 166, 5763-5772.

Misra L, Khurmi N, Trentman TL, 2016. Angioedema: Classification, management and emerging therapies for the perioperative physician. Indian J Anaesth. 60:534-41. doi: 10.4103/0019-5049.187776.

Nair, P., Martin, J.G., Cockcroft, D.C., Dolovich, M., Lemiere, C., Boulet, L.P., O'Byrne, P.M., 2017. Airway Hyperresponsiveness in Asthma: Measurement and Clinical Relevance. J Allergy Clin Immunol Pract. 5: 649659.e2. doi: 10.1016/j.jaip.2016.11.030.

Newton, R., Eddleston, J., Haddad, E.-B., Hawisa, S., Mak, J., Lim, S., Fox, A.J., Donnelly, L.E., Chung, K.F., 2002. Regulation of kinin receptors in airway epithelial cells by inflammatory cytokines and dexamethasone. Eur. J. Pharmacol. 441, 193-202.

Ojiaku, C.A., Yoo, E.J., Panettieri, R.A., Jr., 2017. Transforming Growth Factor $\beta 1$ Function in Airway Remodeling and Hyperresponsiveness. The Missing Link? Am J Respir Cell Mol Biol. 56:432-442. doi: 10.1165/rcmb.2016-0307TR 
Perron MS, Gobeil F Jr, Pelletier S, Regoli D, Sirois P, 1999. Involvement of bradykinin B1 and B2 receptors in pulmonary leukocyte accumulation induced by Sephadex beads in guinea pigs. Eur J Pharmacol. 376:83-9.

Petecchia, L., Sabatini, F., Usai, C., Carnevali, S., Ognibene, M., Vanni, C., Eva, A., Fabbri, L.M., Rossi, G. A., Ricciardolo, F.L.M., 2010. Mechanisms of bradykinin-induced contraction in human fetal lung fibroblasts. Eur. Respir. J. 36, 655-64. doi:10.1183/09031936.00112209

Postma, D., Timens, W., 2006. Remodeling in asthma and chronic obstructive pulmonary disease. Proc Am Thorac Soc $3,434-439$.

Reynolds, C.J., Togias, A., Proud, D., 1999. Airway neural responses to kinins: Tachyphylaxis and role of receptor subtypes. Am. J. Respir. Crit. Care Med. 159, 431-438.

Reynolds, C.J., Togias, A., Proud, D., 2002. Airways hyper-responsiveness to bradykinin and methacholine: effects of inhaled fluticasone. Clin. Exp. Allergy J. 32, 1174-9.

Ricciardolo, F.L.M., Nadel, J. A, Bertrand, C., Yamawaki, I., Chan, B., Geppetti, P., 1994a. Tachykinins and kinins in antigen-evoked plasma extravasation in guinea-pig nasal mucosa. Eur. J. Pharmacol. 261, 127-32.

Ricciardolo, F.L.M., Nadel, J.A., Graf, P.D., Bertrand, C., Yoshihara, S., Geppetti, P., 1994b. Role of kinins in anaphylactic-induced bronchoconstriction mediated by tachykinins in guinea-pigs. Br. J. Pharmacol. 113, 508512.

Ricciardolo, F.L.M., Nadel, J. A, Yoshihara, S., Geppetti, P., Yoishihara, S., 1994c. Evidence for reduction of bradykinin-induced bronchoconstriction in guinea-pigs by release of nitric oxide. Br. J. Pharmacol. 113, 114752.

Ricciardolo, F.L.M., Geppetti, P., Mistretta, a, Nadel, J. a, Sapienza, M. a, Bellofiore, S., Di Maria, G.U., 1996. Randomised double-blind placebo-controlled study of the effect of inhibition of nitric oxide synthesis in bradykinin-induced asthma. Lancet 348, 374-7.

Ricciardolo, F.L.M., Di Maria, G.U., Mistretta, A., Sapienza, M.A., Geppetti, P., 1997. Impairment of bronchoprotection by nitric oxide in severe asthma. Lancet. 350:1297-8.

Ricciardolo, F.L.M., Lovett, M., Halliday, D.A., Nadel, J.A., Kaneko, T., Bunnett, N.W., Geppetti, P., 1998. Bradykinin increases intracellular calcium levels in a human bronchial epithelial cell line via the B2 receptor subtype. Inflamm. Res. 47, 231-5. doi:10.1007/s000110050322

Ricciardolo, F.L.M., Rado, V., Fabbri, L.M., Sterk, P.J., Di Maria, G.U., Geppetti, P., 1999. Bronchoconstriction induced by citric acid inhalation in guinea pigs: role of tachykinins, bradykinin, and nitric oxide. Am. J. Respir. Crit. Care Med. 159, 557-562. doi:10.1164/ajrccm.159.2.9804022 
Ricciardolo, F.L.M., Vergnani, L., Wiegand, S., Ricci, F., Manzoli, N., Fischer, A, Amadesi, S., Fellin, R., Geppetti, P., 2000. Detection of nitric oxide release induced by bradykinin in guinea pig trachea and main bronchi using a porphyrinic microsensor. Am. J. Respir. Cell Mol. Biol. 22, 97-104. doi:10.1165/ajrcmb.22.1.3706

Ricciardolo, F.L.M., Timmers, M.C., Geppetti, P., van Schadewijk, a, Brahim, J.J., Sont, J.K., de Gouw, H.W., Hiemstra, P.S., van Krieken, J.H., Sterk, P.J., 2001. Allergen-induced impairment of bronchoprotective nitric oxide synthesis in asthma. J. Allergy Clin. Immunol. 108, 198-204. doi:10.1067/mai.2001.116572

Ricciardolo, F.L.M., Di Stefano, A., van Krieken, J.H.J.M., Sont, J.K., van Schadewijk, A., Rabe, K.F., Donner, C.F., Hiemstra, P.S., Sterk, P.J., Mauad, T., 2003. Proliferation and inflammation in bronchial epithelium after allergen in atopic asthmatics. Clin. Exp. Allergy J. 33, 905-911.

Ricciardolo FL, Di Stefano A, Sabatini F, Folkerts G, 2006. Reactive nitrogen species in the respiratory tract. Eur J Pharmacol. 533:240-52.

Ricciardolo, F.L.M., Di Stefano, A., Silvestri, M., Van Schadewijk, A., Malerba, M., Hiemstra, P., Sterk, P., 2012. Exhaled nitric oxide is related to bronchial eosinophilia and airway hyperresponsiveness to bradykinin in allergen-induced asthma exacerbation. Int J Immunopathol Pharmacol 25, 175-182.

Ricciardolo, F.L.M., Sorbello, V., Benedetto, S., Defilippi, I., Sabatini, F., Robotti, A., van Renswouw, D.C., Bucca, C., Folkerts, G., De Rose, V., 2012. Bradykinin- and lipopolysaccharide-induced bradykinin B2 receptor expression, interleukin 8 release and "nitrosative stress" in bronchial epithelial cells BEAS-2B: role for neutrophils. Eur. J. Pharmacol. 694, 30-8. doi:10.1016/j.ejphar.2012.07.051

Ricciardolo, F.L.M., Sabatini, F., Sorbello, V., Benedetto, S., Defilippi, I., Petecchia, L., Usai, C., Gnemmi, I., Balbi, B., De Rose, V., Ten Hacken, N.H.T., Postma, D.S., Timens, W., Di Stefano, A., 2013. Expression of vascular remodelling markers in relation to bradykinin receptors in asthma and COPD. Thorax 68, 803-11. doi:10.1136/thoraxjnl-2012-202741

Ricciardolo, F.L.M., Petecchia, L., Sorbello, V., Di Stefano, A., Usai, C., Massaglia, G.M., Gnemmi, I., Mognetti, B., Hiemstra, P.S., Sterk, P.J., Sabatini, F., 2016. Bradykinin B2 receptor expression in the bronchial mucosa of allergic asthmatics: the role of NF-kB. Clin. Exp. Allergy 46, 428-438. doi:10.1111/cea.12676

Riha HM, Summers BB, Rivera JV, Van Berkel MA, 2017. Novel Therapies for Angiotensin-Converting Enzyme Inhibitor-Induced Angioedema: A Systematic Review of Current Evidence. J Emerg Med. 53:662-679. doi:10.1016/j.jemermed.2017.05.037.

Roisman, G., Lacronique, J., Desmazes-Dufeu, N., Carré, C., Le Cae, A., Dusser, D., 1996. Airway responsiveness to bradykinin is related to eosinophilic inflammation in asthma. Am J Respir Crit Care Med 153, 381-390. 
Sabatini, F., Petecchia, L., Usai, C., Silvestri, M., Rossi, G.A., Miller-Larsson, A., Ricciardolo, F.L.M., 2012. Pharmacological modulation of the bradykinin-induced differentiation of human lung fibroblasts: effects of budesonide and formoterol. J. Asthma Off. J. Assoc. Care Asthma 49, 1004-1011. doi:10.3109/02770903.2012.729633

Sabatini, F., Luppi, F., Petecchia, L., Stefano, A.D., Longo, A.M., Eva, A., Vanni, C., Hiemstra, P.S., Sterk, P.J., Sorbello, V., Fabbri, L.M., Rossi, G.A., Ricciardolo, F.L.M., 2013. Bradykinin-induced asthmatic fibroblast/myofibroblast activities via bradykinin B2 receptor and different MAPK pathways. Eur. J. Pharmacol. 710, 100-109. doi:10.1016/j.ejphar.2013.03.048

Sainz, I.M., Pixley, R.A., Colman, R.W., 2007. Fifty years of research on the plasma kallikrein-kinin system: from protein structure and function to cell biology and in-vivo pathophysiology. Thromb. Haemost. 98, 77-83.

Sato, E., Nelson, D.K., Koyama, S., Hoyt, J.C., Robbins, R.A., 2000. Bradykinin stimulates eotaxin production by a human lung fibroblast cell line. J. Allergy Clin. Immunol. 106, 117-123. doi:10.1067/mai.2000.107400

Schuelert, N., Just, S., Corradini, L., Kuelzer, R., Bernloehr, C., Doods, H., 2015. The bradykinin B1 receptor antagonist BI113823 reverses inflammatory hyperalgesia by desensitization of peripheral and spinal neurons. Eur. J. Pain Lond. Engl. 19, 132-142. doi:10.1002/ejp.573

Shirasaki, H., Kanaizumi, E., Him,i T., 2009. Immunohistochemical localization of the bradykinin B1 and B2 receptors in human nasal mucosa. Mediators Inflamm. 2009:102406. doi: 10.1155/2009/102406.

Sinert R, Levy P, Bernstein JA, Body R, Sivilotti MLA, Moellman J, Schranz J, Baptista J, Kimura A, Nothaft W; CAMEO study group, 2017. Randomized Trial of Icatibant for Angiotensin-Converting Enzyme InhibitorInduced Upper Airway Angioedema. J Allergy Clin Immunol Pract.;5:1402-1409.e3. doi:10.1016/j.jaip.2017.03.003.

Sodhi CP, Wohlford-Lenane C, Yamaguchi Y, Prindle T, Fulton WB, Wang S, McCray PB Jr, Chappell MC, Hackam DJ, Jia H, 2017. Attenuation of pulmonary ACE2 activity impairs inactivation of des-Arg9 bradykinin/BKB1R axis and facilitates LPS-induced neutrophil infiltration. Am J Physiol Lung Cell Mol Physiol. :ajplung.00498.2016. doi: 10.1152/ajplung.00498.2016.

Tabet, Y., Sirois, M., Sirois, C., Rizcallah, E., Rousseau, É., 2013. Relationship between bradykinin-induced relaxation and endogenous epoxyeicosanoid synthesis in human bronchi. Am. J. Physiol. Lung Cell. Mol. Physiol. 304, L562-9. doi:10.1152/ajplung.00379.2012.

Thornton, M.A., Akasheh, N., Walsh, M.T., Moloney, M., Sheahan, P.O., Smyth, C.M., Walsh, R.M., Morgan, R.M., Curran, D.R., Walsh, M.T., Gleich, G.J., Costello, R.W., 2013. Eosinophil recruitment to nasal nerves after allergen challenge in allergic rhinitis. Clin Immunol. 147:50-7. doi: 10.1016/j.clim.2013.02.008. 
Valenti, C., Cialdai, C., Giuliani, S., Tramontana, M., Quartara, L., Maggi, C.A., 2008. MEN16132, a kinin B2 receptor antagonist, prevents the endogenous bradykinin effects in guinea-pig airways. Eur J Pharmacol. 579:350-6.

Vallese, D., Ricciardolo, F.L.M., Gnemmi, I., Casolari, P., Brun, P., Sorbello, V., Capelli, A., Cappello, F., Cavallesco, G.N., Papi, A., Chung, K.F., Balbi, B., Adcock, I.M., Caramori, G., Di Stefano, A., 2015. Phospho-p38 MAPK expression in COPD patients and asthmatics and in challenged bronchial epithelium. Respiration. 89:329-42. doi:10.1159/000375168.

Vancheri, C., Gili, E., Failla, M., Mastruzzo, C., Salinaro, E.T., Lofurno, D., Pistorio, M.P., La Rosa, C., Caruso, M., Crimi, N., 2005. Bradykinin differentiates human lung fibroblasts to a myofibroblast phenotype via the B2 receptor. J. Allergy Clin. Immunol. 116, 1242-8. doi:10.1016/j.jaci.2005.09.025

Van Schoor, J., Joos, G.F., Pauwels, R.A.,2000 Indirect bronchial hyperresponsiveness in asthma: mechanisms, pharmacology and implications for clinical research. Eur Respir J. 16, 514-33

Vasquez-Pinto, L.M.C., Nantel, F., Sirois, P., Jancar, S., 2010. Bradykinin B(1) receptor antagonist R954 inhibits eosinophil activation/proliferation/migration and increases TGF-beta and VEGF in a murine model of asthma. Neuropeptides 44, 107-13. doi:10.1016/j.npep.2009.11.001

Xu, Y., Zhang, Y., Cardell, L.O., 2010. Nicotine enhances murine airway contractile responses to kinin receptor agonists via activation of JNK- and PDE4-related intracellular pathways. Respir Res. 11, 13. doi: 10.1186/1465-9921-11-13.

Xu, Y., Cardell, L.-O., 2014. Nicotine impairs cyclooxygenase-2-dependent kinin-receptor-mediated murine airway relaxations. Toxicol. Appl. Pharmacol. 275, 12-21. doi:10.1016/j.taap.2013.12.013

Yamawaki, I., Geppetti, P., Bertrand, C., Chan, B., Nadel, J.A., 1994. Airway vasodilation by bradykinin is mediated via B2 receptors and modulated by peptidase inhibitors. Am. J. Physiol. 266, L156-162.

Yoshihara, S., Geppetti, P., Hara, M., Linden, A., Ricciardolo, F.L.M., Chan, B., Nadel, J.A. 1996. Cold air-induced bronchoconstriction is mediated by tachykinin and kinin release in guinea pigs. Eur. J. Pharmacol. 296, 291296.

Wenzel, S., 2012. Asthma phenotypes: the evolution from clinical to molecular approaches. Nature Medicine 18, 716725.

Zhang, Y., Adner, M., Cardell, L.-O., 2004. Up-regulation of bradykinin receptors in a murine in-vitro model of chronic airway inflammation. Eur. J. Pharmacol. 489, 117-26. doi:10.1016/j.ejphar.2004.02.033

Zhang, Y., Adner, M., Cardell, L.-O., 2007. IL-1beta-induced transcriptional up-regulation of bradykinin B1 and B2 receptors in murine airways. Am. J. Respir. Cell Mol. Biol. 36, 697-705. doi:10.1165/rcmb.2005-0369OC 
Zhang, Y., Cardell, L.-O., Edvinsson, L., Xu, C.-B., 2013. MAPK/NF-кB-dependent upregulation of kinin receptors mediates airway hyperreactivity: a new perspective for the treatment. Pharmacol. Res. 71, 9-18. doi:10.1016/j.phrs.2013.02.004

Zimmerman, B., Simaan, M., Akoume, M.-Y., Houri, N., Chevallier, S., Séguéla, P., Laporte, S.A., 2011. Role of ßarrestins in bradykinin B2 receptor-mediated signalling. Cell. Signal. 23, 648-59.

doi:10.1016/j.cellsig.2010.11.016 